\title{
Multiple Stressors Influence Salt Marsh Recovery after a Spring Fire at Mugu Lagoon, CA
}

\author{
Lauren N. Brown ${ }^{1}$ [D $\cdot$ Jordan A. Rosencranz ${ }^{2} \cdot$ Katherine S. Willis $^{1} \cdot$ Richard F. Ambrose $^{2,3} \cdot$ Glen M. MacDonald ${ }^{1,2}$
}

Received: 22 February 2019 / Accepted: 30 July 2019 / Published online: 14 August 2019

(C) The Author(s) 2019

\begin{abstract}
This paper presents the first record of fire in Pacific coast salt marshes; the 1993 Green Meadows Fire and the 2013 Camarillo Springs Fire burned an area of Salicornia-dominated salt marsh at Point Mugu, CA. These fires inspire concern about resiliency of ecosystems not adapted to fire, already threatened by sea-level rise (SLR), and under stress from extreme drought. We monitored vegetation percent cover, diversity, and soil organic carbon (SOC) in burned and unburned areas of the salt marsh following the 2013 Camarillo Springs Fire and used remotely sensed Normalized Vegetation Difference Index (NDVI) analysis to verify the in situ data. Two years following the fire, vegetation percent cover in burned areas was significantly lower than in unburned areas, with dominant-species change in recovered areas, and NDVI was lower than pre-fire conditions. Multi-year disturbance, such as fire, presents challenges for salt marsh resilience and dependent species, especially in sites facing multiple stressors. With anticipated higher temperatures, increased aridity, extreme drought, and higher frequency fires becoming a reality for much of the Pacific coast, this study indicates that fire in Salicornia-dominated marshes is a vulnerability that will need to be addressed differently from other grass- or reed-dominated marsh systems.
\end{abstract}

Keywords Fire $\cdot$ Recovery $\cdot$ Soil organic matter $\cdot$ NDVI $\cdot$ Salt marsh $\cdot$ Southern California

\section{Introduction}

In the past 200 years population growth and urbanization caused the destruction or conversion of an estimated $75 \%$ of the salt marsh habitat in California (Stein et al. 2014). According to recent ecosystem vulnerability models that use projected rates of sea-level rise (SLR) from the IPCC RCP 8.5 scenarios (Stocker et al. 2013) up to $99 \%$ of vegetated salt marsh habitat may be converted to tidal flats by 2100

Electronic supplementary material The online version of this article (https://doi.org/10.1007/s13157-019-01210-6) contains supplementary material, which is available to authorized users.

Lauren N. Brown

LNBrown@ucla.edu

1 UCLA Geography Department, 1255 Bunche Hall, Box 951524, Los Angeles, CA 90095, USA

2 UCLA Institute of the Environment and Sustainability, LaKretz Hall, 619 Charles E Young Dr E \#300, Los Angeles, CA 90024, USA

3 UCLA Environmental Health Sciences, 650 Charles Young Dr. S., 56-070 CHS Box 951772, Los Angeles, CA 90095, USA
(Thorne et al. 2018; Doughty et al. 2019). These estimates do not include recent uncertainty surrounding continental ice sheet stability that could add an additional meter or more to sea-level rise projections in worst-case scenarios (Griggs et al. 2017) and result in more rapid loss of salt marsh habitat; nor do they take into account some of the more dynamic, storm-, flooding-, and erosion- driven changes which will likely occur under anthropogenic climate change conditions (Barnard et al. 2019). Landward migration is the natural salt marsh response to increases in SLR, but many natural and human barriers may inhibit migration along the California coast (Pethick 2001; Kirwan et al. 2016). The remaining salt marsh habitat which supports endangered species, such as the Belding's savannah sparrow (Passerculus sandwichensis beldingi), and provides a wealth of ecosystem services (Powell 1993; Costanza et al. 1997; Chmura et al. 2003; Barbier et al. 2011), is therefore even more vulnerable to natural and human-caused stressors, which could further increase the rate of habitat loss.

Fire has not been documented as a natural stressor for Pacific coast salt marshes dominated by Salicornia pacifica (pickleweed). Although fire is relatively common in reed- or grass-dominated salt marshes (Nyman and Chabreck 1995; Salvia et al. 2012), to date we found no peer-reviewed 
literature regarding incidents of fire in US Pacific coast or S. pacifica-dominated salt marshes. Salt marshes in the California Mediterranean-type climate experience a fallwinter dormant season when above ground biomass is either dead or desiccated (Mahall and Park 1976), conditions which would favor fire. Given California's winter rain regime, fires have historically been less frequent or intense in the late fall and winter, but rising temperatures and prolonged drought are producing a lengthened fire season in regions such as Southern California (Yoon et al. 2015). This longer fire season is further exacerbated by higher temperatures, drought, and increased population leading to greater fire risk for many areas (Westerling et al. 2006). Such changes in fire regimes could mean that the risk of fire for $S$. pacifica-dominated salt marshes, too, is increasing.

The best comparison of fire in similar habitats are the marshes of the southeastern US. These marshes are often dominated by Spartina spp. (cordgrass) or Schoenoplectus spp. (bulrush) and have well-established, seasonal fire regimes. Fire occurs naturally from lightening (Loveless 1959), spontaneous combustion (Viosca 1932), and as a management practice used by humans for several hundred years (Lynch 1941; Smith 1942; Uhler 1944; O’Neil 1949; Stewart 1963; Komarek 1975; Bickford et al. 2012; Kern and Gregory Shriver 2014). Habitat managers use controlled burns to reduce wildfire as well as employ low-intensity burns to increase productivity and promote species diversity of both flora and fauna in Louisiana saline and brackish marshes (Gabrey and Afton 2000), Chesapeake Bay brackish marshes (Kern and Gregory Shriver 2014), and saline marshes on the coast of Argentina (Isacch et al. 2004). Studies show that a one to 5 year return interval on controlled burning will continue to stimulate high productivity without negative ecosystem impacts in both freshwater systems dominated by Spartina spp. (Johnson and Knapp 1993) and brackish systems with a mix of Spartina spp., Schoenoplectus spp., and Distichlis spp. (Flores et al. 2011). For Schoenoplectus spp. and Spartina spp. marshes, biomass removal has been shown to be the most likely driver of increases in productivity (Bickford et al. 2012). Brackish salt marshes in Chesapeake Bay were even observed to have attained $100 \%$ vegetation recovery within a year of fire (Nyman and Chabreck 1995).

The long-term effects of fire on soil or ecosystem function are not as well documented, even for salt marshes with a fire regime. Fire's effects on soil depends highly upon the intensity of the burn, the fate of ash, and the hydrology of the salt marsh immediately following the fire (Lynch 1941; Nyman and Chabreck 1995). For example, more intense burns that completely remove vegetation cover and damage or expose soils to direct solar radiation cause low soil moisture and further slow nutrient recovery of the soil (Salvia et al. 2012). Studies of soil dynamics show more severe and longer-lasting effects on soil organic matter (SOM) occur with greater burn intensity (Salvia et al. 2012), while soil dynamics after lower-intensity fires show an initial decrease in SOM followed by increased levels for 9 months as vegetation recovers (Schmalzer and Hinkle 1992). For this reason, occasional or managed burns have been used to stimulate growth and prevent more severe burning which might affect ecosystem services in the long term. But relatively few studies have documented how fire impacts ecosystem function or salt marsh resiliency over such time periods.

At the end of the peak spring growth period in May 2013 the Camarillo Springs Fire, which started from roadside ignition, burned approximately 24,000 acres of chaparral vegetation and a section of the high-elevation, infrequently-inundated salt marsh at Naval Base Ventura County Point Mugu (Springs Fire Incident Information 2013). The 2013 Camarillo Springs Fire occurred during a period of unusually extreme drought in California which started in 2012 (Griffin and Anchukaitis 2014); a drought severe enough to have caused changes to the geomorphologic function of nearby streams following the fire event (Florsheim et al. 2017). This pattern of burning is similar to that of the Green Meadows Fire that occurred in October 1993 and burned the same area of salt marsh at Point Mugu (Fig. 1), although the Green Meadows Fire did not occur during a drought nor outside of the historic fire season. These events present evidence for a recurring pattern of burning in a $S$. pacifica-dominated salt marsh and indicate a need for better understanding of fire dynamics in Pacific coast salt marsh habitats, specifically in terms of vegetation recovery period and soil dynamics.

With so little information on the effects of fire in Pacific coast salt marsh ecosystems, we find the disturbance from the 2013 Camarillo Springs Fire provides an important case study and possible early warning of a new vulnerability for salt marshes facing multiple stressors along the Pacific coast. This paper combines field survey and remote sensing to assess the impact of the disturbance and track the recovery of salt marsh vegetation at Point Mugu after the 2013 Camarillo Springs Fire. Using a control-impact design, we evaluate percent cover in situ to assess vegetation recovery, species composition and diversity, and soil organic carbon (SOC). We assessed vegetation recovery remotely using Normalized Difference Vegetation Index (NDVI), which is positively correlated with estimates of percent cover (Purevdorj et al. 1998) and has been used to estimate vegetation recovery following fire (Díaz-Delgado et al. 2003). This study contributes to the understanding of salt marsh recovery from small-scale disturbance under droughtstressed conditions to identify future vulnerabilities for salt marsh ecosystems facing multiple stressors. 
Fig. 1 Area Map Showing Fire Extent. Map of the 1993 Green Meadows Fire and 2013 Camarillo Springs Fire extent at Mugu Lagoon. Wetland outline was obtained from The Pacific Institute shapefile of wetlands below or within $100 \mathrm{~m}$ of mean higher high water, fire perimeters were obtained from CalFire Fire Perimeters Version 14_2 and basemap is open source ESRI Gray (light)

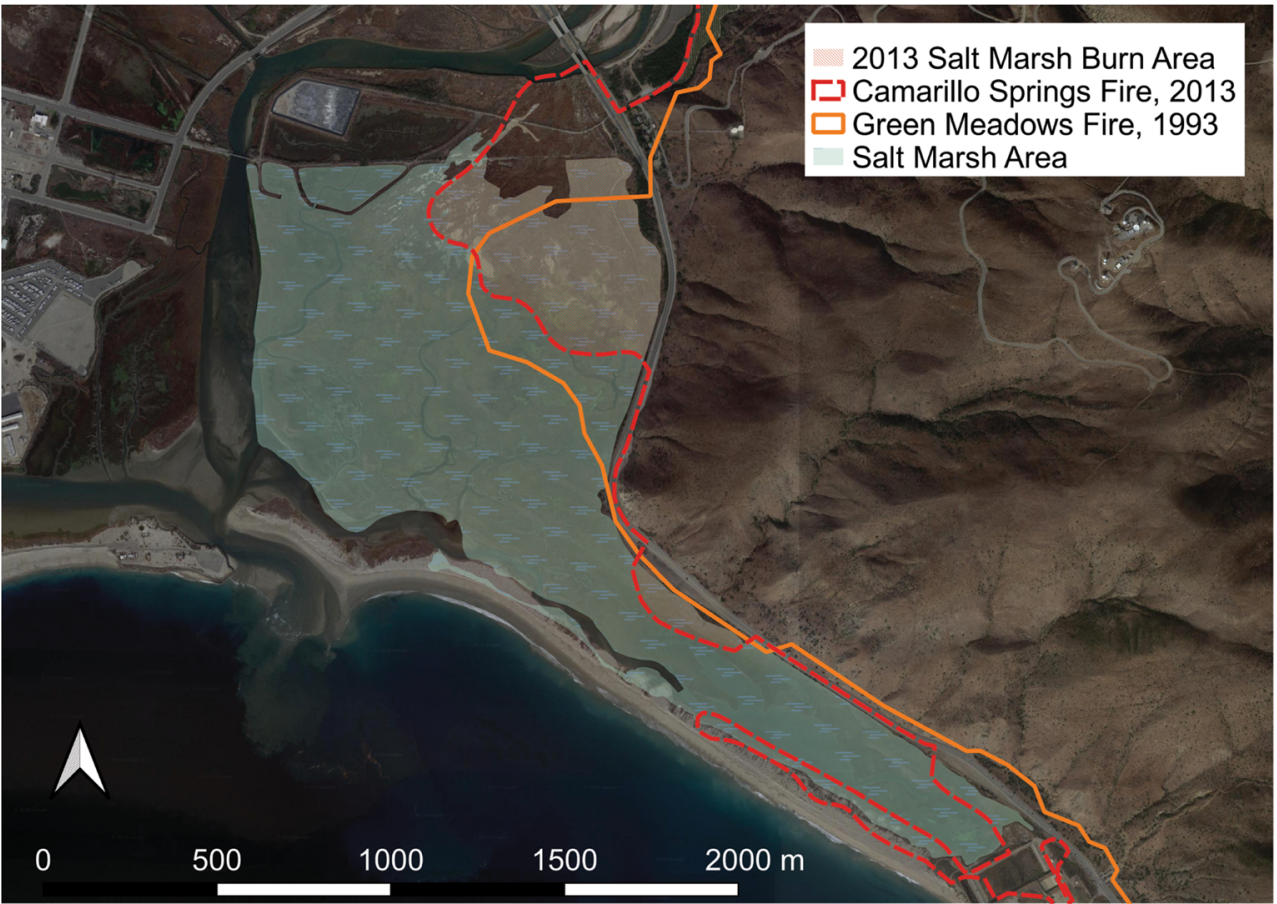

\section{Methods}

\section{Study Site}

The vegetated salt marsh at the Naval Base Ventura County Point Mugu is located at $34.116 \mathrm{~N}, 119.116 \mathrm{~W}$ and covers approximately $1.09 \mathrm{~km}^{2}$ (Onuf 1987; Thorne et al. 2016). Calleagus Creek, channelized since the early twentieth century, empties into the central basin of the salt marsh. Further human impacts on the salt marsh include the intensive agriculture of the surrounding region starting in the twentieth century (Onuf 1987). The salt marsh is dominated by S. pacifica, and a host of other common Pacific coast salt marsh species such as Distichlis spicata (saltgrass), Frankenia grandifolia (alkali heath), Jaumea carnosa (fleshy jaumea), Limonium californicum (sea lavender), Suaeda californica (seablite), Batis maritima (saltwort), and Distichlis littoralis (shore grass). The ecotone between salt marsh and chaparral vegetation at Mugu Lagoon is commonly colonized by upland species such as Baccharis pilularis spp. consanguinea (coyote brush) as well as exotic weeds such as Brassica rapa (mustard), Ricinus communis (castor bean), Arundo donax (giant reed), and Polypogon monspeliensis (rabbitsfoot grass).

Mugu Lagoon has a Mediterranean-type climate with mild temperatures and precipitation occurring during the winter and spring months. Temperature and precipitation normals as recorded by the NOAA station at Camarillo are $15.8{ }^{\circ} \mathrm{C}$ with $38.7 \mathrm{~cm}$ rainfall (https://www.ncdc.noaa.gov/cdo-web/). The 1993 Green Meadows Fire occurred in a year where mean annual temperature was lower than station normals $\left(14.4{ }^{\circ} \mathrm{C}\right)$ and $94.5 \mathrm{~cm}$ rainfall was recorded, but particularly strong
Santa Ana winds in October contributed to fire conditions (Reed and Alvarez 1993). The Palmer Drought Severity Index (PDSI) for Ventura County during 1993 indicates that there was no drought for the 1992-1993 period. During this paper's remote sensing study period of March 2010 to May 2015 , temperatures averaged $20.5{ }^{\circ} \mathrm{C}$ and rainfall averaged $16.2 \mathrm{~cm}$ per year, an increase in temperature and reduction in annual precipitation from station normals. PDSI data from a $4 \mathrm{X} 4 \mathrm{~km}^{2}$ region centered at $34.108 \mathrm{~N}, 119.083 \mathrm{~W}$ show that there have been three periods of increasingly severe drought occurring since 2005 (Palmer 1965; Abatzoglou et al. 2017) [Supplemental Fig. 1]. The drought in which the Camarillo Springs Fire occurred started in early 2012 and reached extreme status a month preceding the fire in April 2013. Extreme drought conditions continued throughout most of the study period, with only a brief interlude of severedrought status during the rains in winter 2014.

\section{Site Selection and Description}

Much of the area burned by the 2013 Camarillo Springs Fire inside the Mugu Lagoon reserve had been vegetated by upland transition species, such as B. pilularis, or covered by salt pans [some of which are outlined on the map in Fig. 2]. Although no published literature or grey literature exists pertaining to vegetation recovery following the 1993 Green Meadows Fire, this mix of upland, high marsh, and salt pan habitat in the Green Meadows burn area may be a remnant of recovery following that event. The site established in 2013 is located in the central basin of the Mugu Lagoon salt marsh, an area that had been dominated by S. pacifica before the 
Fig. 2 Map of Study Site. Site map depicting the seven transects, A to $\mathrm{G}$ from left to right. Dots on each transect indicate the 21 quadrats in burned areas (three on each transect) and seven quadrats in unburned areas (one quadrat on each transect). Wetland outline was obtained from The Pacific Institute shapefile of wetlands below or within $100 \mathrm{~m}$ of mean higher high water, fire perimeters were obtained from CalFire Fire Perimeters Version 14_2 and basemap is open source in QGIS from OpenStreetMap

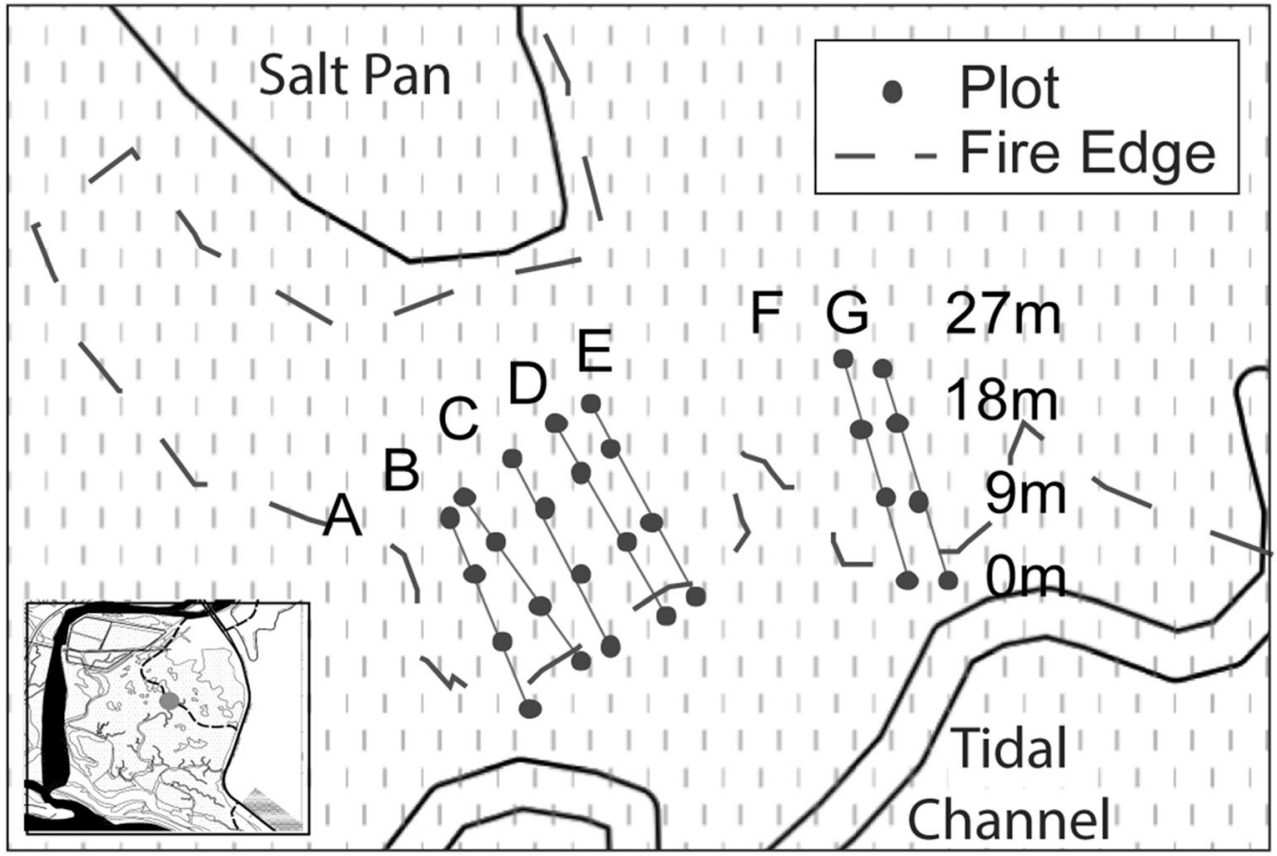

Camarillo Springs Fire. Study transects occupy an area of burned salt marsh adjacent to unburned $S$. pacifica-dominated salt marsh. The study site is tidally-influenced habitat intersected by small tidal channels and suited for salt marsh species. However, the proximity of the salt pan northwest of transects [seen in Fig. 2] indicates the study site sits at the upper limits of tidal reach. High resolution Digital Elevation Models (DEMs) produced by the United States Geologic Survey (Takekawa et al. 2015) indicate that fire burned areas of marsh 1.72 to $2.53 \mathrm{~m}$ in elevation with plots occupying an area $1.7-1.8 \mathrm{~m}$ in elevation.

Establishment of the sampling plots and collection of data in the first survey took place on June 11, 2013, 5 weeks after the salt marsh burned. Seven $27 \mathrm{~m}$-long transects $(A-G)$ were established roughly perpendicular to the boundary between burned and unburned salt marsh. Transects were laid out on a grid with $6 \mathrm{~m}$ between each. Because of a channel which bisects the plots, the two final transects $(F$ and $G$ ) were located about $10 \mathrm{~m}$ east of transect $\mathrm{E}$ and slightly rotated to remain perpendicular to the burn edge. Along each transect four quadrats $\left(0.25 \mathrm{~m}^{2}\right)$ were distributed evenly, totaling 28 study plots. Of those 28 plots, one quadrat located approximately $1 \mathrm{~m}$ into unburned salt marsh vegetation marked the start of each transect, for a total of seven quadrats plots placed in unburned salt marsh area. Unburned plots were placed within green, undamaged vegetation with a small buffer of healthy vegetation at the edge of the burn zone to prevent edge effects. The remaining 21 plots were placed at equal intervals into the burned area, three per transect (Fig. 2). All quadrats were marked with PVC piping for repeated sampling.

\section{Percent Cover}

Nine times over the course of the 2-years study period quadrats were photographed [Supplemental Fig. 2] and total vegetation percent cover and percent cover by species were estimated. Percent cover estimates were made consistently by the same researcher. Percent cover estimates totaled to $100 \%$ and did not separate canopy layers. Vegetation that was dormant was counted towards percent cover estimates, but vegetation that was browned or dead was not included in totals. For the initial surveys, the number of plant recruits, defined as sprouts from seed, in each quadrat was counted. Recruits were counted only if the base of plant was within the quadrat. If multiple shoots were clearly associated with a single plant, only one recruit was recorded. Salicornia pacifica shoots were frequently the result of sprouting from remaining adult plant roots, making the enumeration of individuals difficult, and those sprouts were not included in the recruit count. Salicornia pacifica plants were counted only if they were separated by more than $1 \mathrm{~cm}$; all $S$. pacifica shoots within $1 \mathrm{~cm}$ of each other were counted as a single individual. After the initial recruitment period in the fall of 2013, only percent cover estimates were made.

Percent cover estimates were first used to estimate recovery by comparing unburned and burned plots with a spline fit (unburned $n=7$, burned $n=21$; standard error) (Fig. 3a). Then percent cover in burned plots was separated by distance to test the effect of distance from unburned vegetation on recovery. A spline fit for each unburned salt marsh distance category, near (9 m distant), mid (18 m distant), and far (27 m distant), was used ( $n=7$, standard error) (Fig. 3b). 


\section{Species Composition, Diversity, and Evenness}

Percent cover data by species was averaged for unburned and burned plots at each sampling period (Fig. $3 \mathrm{c}$ and d). The Simpson's index of diversity (ID), an index which is not as sensitive to species richness as the Shannon diversity index (Nagendra 2002), was used to compare species composition between plots and timepoints. Average Simpson's ID for unburned and burned plots was plotted by time and a simple linear regression was used to interpret species diversity change over time (Fig. 4).

Nonmetric Multidimensional Scaling (NMDS) compared species composition between burned and unburned sites throughout the study period using the $\mathrm{R}$ package, Vegan (RC Team 2013; Oksanen 2015). Percent abundance of each species was transformed by taking the square root to reduce the influence of the most and least abundant groups. A distance matrix between sites was calculated using the Sorenson (Bray-Curtis) dissimilarity index. Sites were plotted in two-dimensional space with stress $<0.15$. A $95 \%$ confidence interval ellipse was drawn around burned and unburned sites and species variables were factor fitted to the NMDS major axes to examine structure of the data. Within burned and unburned

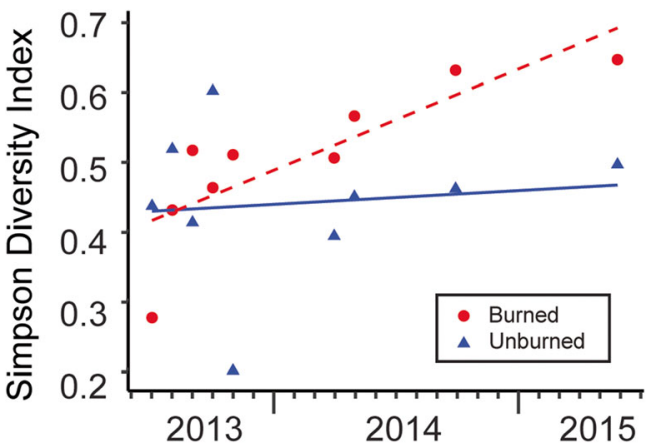

Fig. 4 Simpson's Diversity Index. Simpson's Diversity Index (ID) averaged for burned and unburned plots for each observation during the study period with linear trendlines. Unburned plots show no trend in Simpson's ID [ $\left.\mathrm{R}^{2}=0.01 ; p=0.77\right]$ while burned plots show a slight increase in Simpson's ID over time $\left[\mathrm{R}^{2}=0.68 ; p=0.006\right]$

sites, plots were connected in temporal order to elucidate any trends over time (Fig. 5).

\section{Soil Organic Carbon}

During the six vegetation surveys from June 2013 - April 2014, soil sampling for lab analysis took place. Three transects were analyzed for SOC, selected starting from A and
Fig. 3 Vegetation Percent Cover and Species

Composition. Vegetation for the study period of June 2013 -

May 2015 seen as (a) a spline fit of percent cover for all unburned (solid line) and burned (dashed line) quadrats with shaded standard error, (b) a spline fit of percent cover in unburned quadrats with percent cover in burned plots sorted by distance, with shaded standard error, and asterisks indicating significance levels of difference in recovery between plots $9 \mathrm{~m}$ from unburned marsh compared to plots $27 \mathrm{~m}$ from unburned marsh, (c) average unburned quadrat species composition as a percentage of cover present, and (d) average burned quadrat species composition as a percentage of cover present ( $c$ and $\mathrm{d}$ are plotted out of $100 \%$ to make species differences visible for those time periods which have $<10 \%$ cover, and they do not reflect relative cover between time periods or treatments) a)

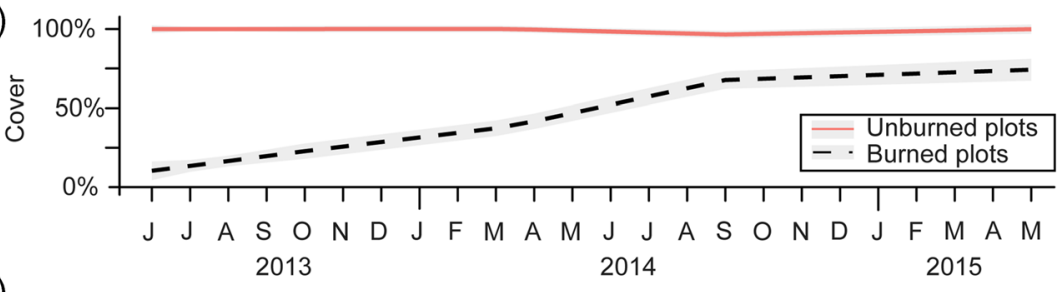

b)

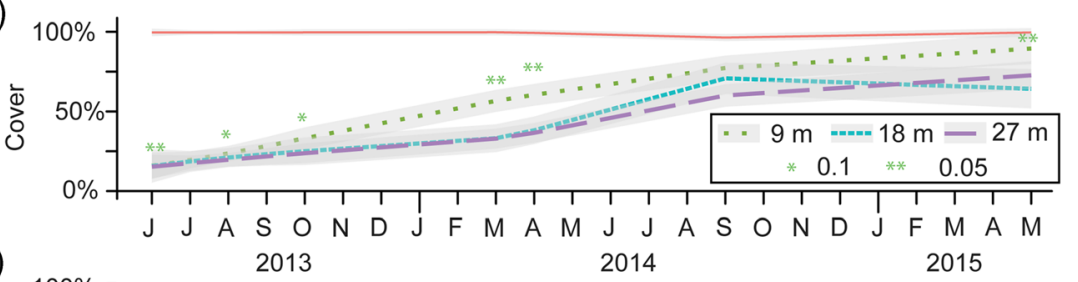

c) 2013

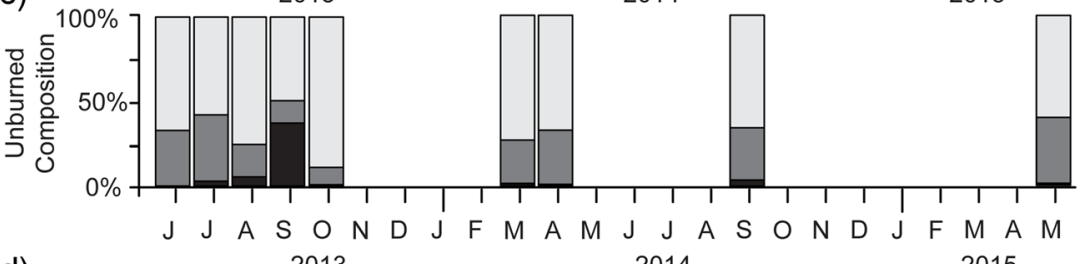

d)

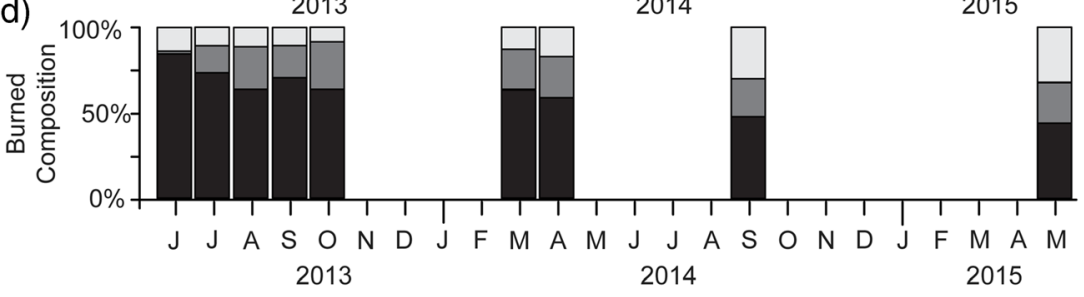

DiSp $\square$ FrGr $\square$ SaPa 
measuring every other transect (A, C, and E). A 3-5 cm depth soil sample was extracted adjacent to the plot for a total of nine burned-area samples and three unburned-area samples. SOM was analyzed using loss on ignition (LOI). One cubic centimeter of sediment was dried, weighed, and burned in a furnace at $550{ }^{\circ} \mathrm{C}$ for $4 \mathrm{~h}$ (Heiri, Lotter, and Lemcke, 2001). Percent SOM was converted to an estimate of percent carbon using Eq. 1 taken from Craft et al. (1991) who described the relationship between organic matter determined from LOI and organic carbon measured by elemental analysis.

$$
\begin{aligned}
\text { Organic } \mathrm{C}= & (0.40 \pm 0.01) \mathrm{LOI} \\
& +(0.0025 \pm 0.003) \mathrm{LOI}^{2}
\end{aligned}
$$

Average organic carbon for unburned and burned plots was plotted with a standard error in Fig. 6.

\section{Remote Sensing}

A coastal salt marsh shapefile was obtained from the Pacific Institute, created as a filtered subset of wetlands below or within $100 \mathrm{~m}$ of mean higher high water (http://www. pacinst.org/reports/sea_level_rise), and was used to create shapefiles for Mugu Lagoon. Fire shapefiles for the 2013 Camarillo Springs Fire and the 1993 Green Meadows Fire were extracted from the CalFire Fire Perimeters Version 14 2 (http://frap.cdf.ca.gov/data/frapgisdata-sw-fireperimeters download). The shapefile for Mugu was clipped using the shapefile of the 2013 Camarillo Springs Fire to create a burned area shapefile for analysis. This burned area shapefile (red shading on Fig. 1) was used to do the following analysis.

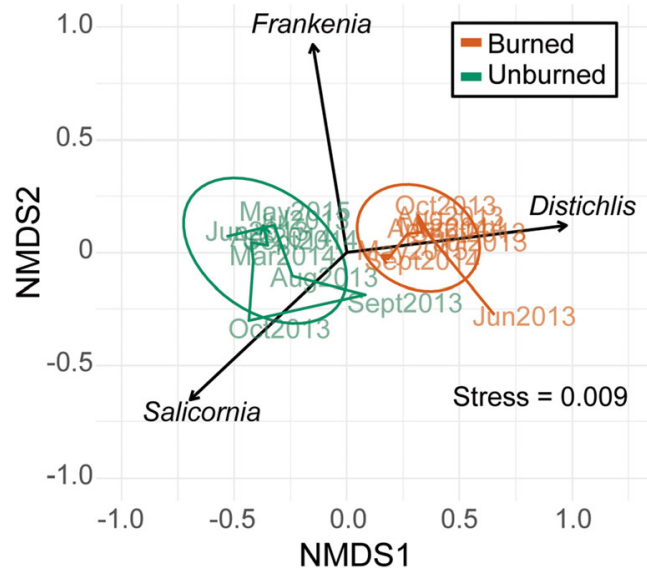

Fig. 5 NMDS Plot for Axes 1 and 2 of Species Composition. Species composition for all timepoints was plotted using non-metric multidimensional scaling (NMDS). Stress value was 0.009. Ellipses indicate the 95\% confidence interval of burned and unburned plot positions in nondimensional space. Species variables were fitted to NMDS axes and are plotted with arrows. Timepoints were connected by a line for burned and unburned plots and show trends in species composition over the duration of the study

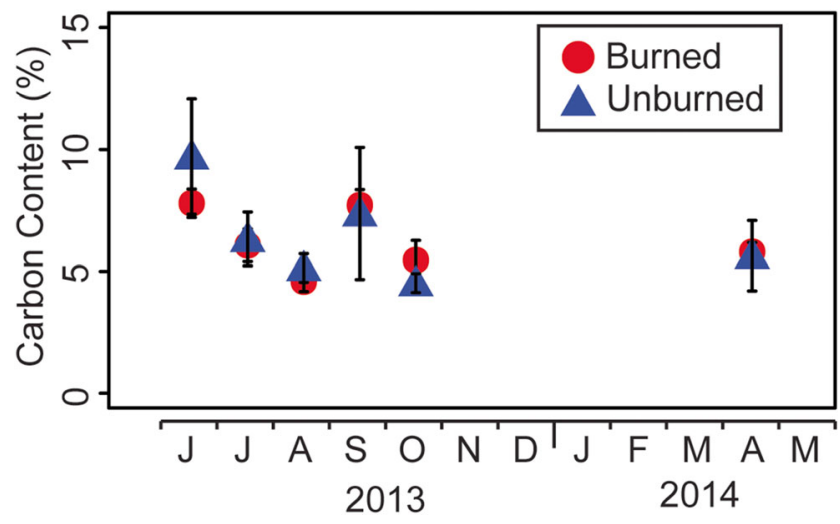

Fig. 6 Soil Organic Carbon. Average soil organic carbon (SOC) for unburned and burned plots from June 2013 to May 2014. Error bars show one standard error

NASA MODIS 16-days composite imagery ( $250 \mathrm{~m}$ spatial resolution MOD13Q1 tiles h08v04, h08v05, h09v04) were downloaded from NASA/USGS (https://lpdaac.usgs.gov/ dataset_discovery/modis/modis_products_table/mod13q1) for March 2010 - April 2015 of Point Mugu and its surroundings. NDVI was calculated using a ratio of measured albedo $(\alpha)$ using MODIS spectral reflectance data:

$N D V I=\frac{\alpha_{0.86 \mu \mathrm{m}}-\alpha_{0.65 \mu \mathrm{m}}}{\alpha_{0.86 \mu \mathrm{m}}+\alpha_{0.65 \mu \mathrm{m}}}$

Time series for NDVI was plotted using mean NDVI. Data were smoothed using a Savitzky-Golay filtering algorithm which uses a local polynomial least squares fit along a moving window to smooth noisy data. This method of analysis for NDVI data was introduced by Chen et al. (2004) and has been shown to be effective in reducing noise introduced by cloud cover and atmospheric variability in MODIS time series. Because NDVI can respond to short-term temperature or precipitation events, regional temperature, precipitation, PDSI, and burned-area NDVI are compared in Fig. 7. Contemporaneous temperature and precipitation data were obtained from the NOAA Climate Data Online website, station USW00023136 (https://www.ncdc.noaa.gov/cdo-web/). PDSI data were taken from a $4 \mathrm{X} 4 \mathrm{~km}^{2}$ region centered on $34.108 \mathrm{~N}, 119.083 \mathrm{~W}$; data are a monthly self-calibrated timescale downloaded from the West Wide Drought Tracker webpage (Abatzoglou et al. 2017).

\section{Results}

\section{Initial Sampling Period}

During initial sampling, 1 month following the 2013 Camarillo Springs Fire, unburned plots were estimated to have $100 \%$ cover, with a mix of D. spicata, F. grandifolia, and 
Fig. 7 Temperature, Precipitation, PDSI, and NDVI. Remote sensing analysis for the period of March 2010 to April 2015 with a average temperature and precipitation at nearest NOAA weather station (Mugu Lagoon), b PDSI, and $\mathbf{c}$ a Savitzky-Golay filter of mean NDVI a)

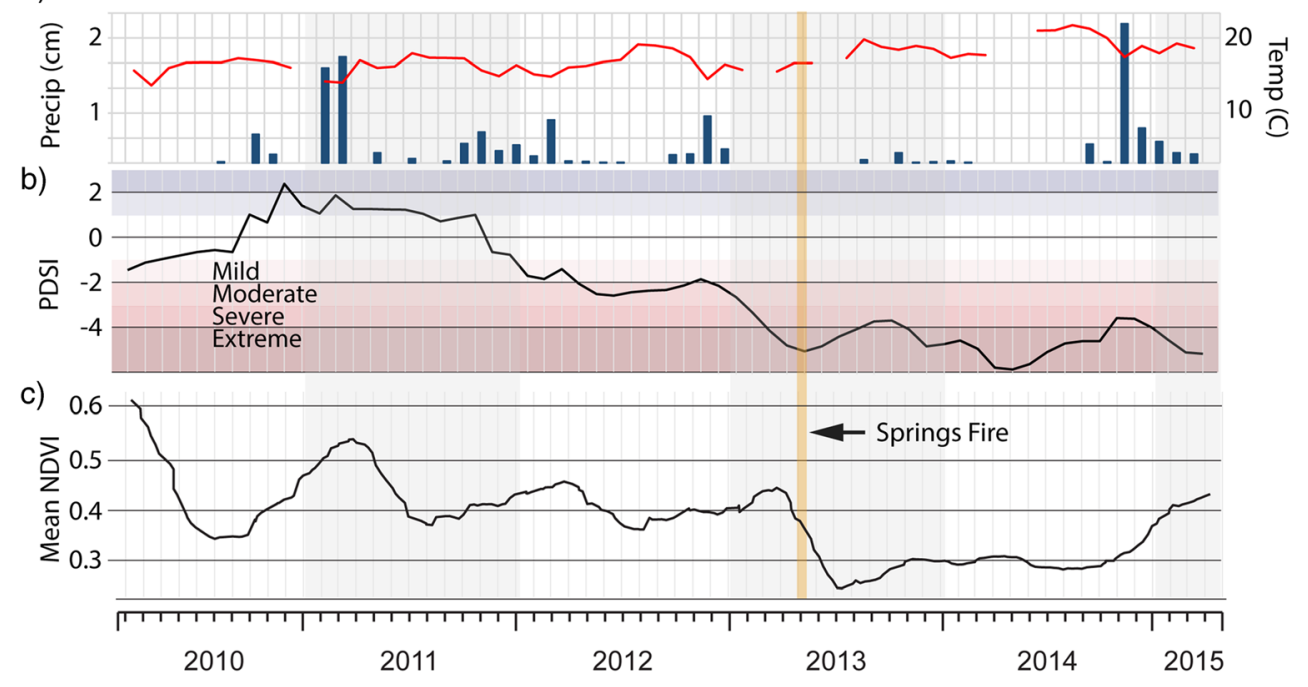

S. pacifica; in contrast, average estimated percent cover for plots located in burned areas was $<1 \%$, with seven of 21 plots devoid of vegetation. Distichlis spicata was the most prevalent species in the burned plots, having an average of 6.4 shoots per plot (range: $0-24$; present in 12 of 21 plots) compared to an average of 0.3 shoots for $F$. grandifolia (range: 0 4; present in three of 21 plots) and average 0.4 shoots for $S$. pacifica (range: $0-4$; present in three of 21 plots) [Supplemental Table 1].

SOC measured from soil samples taken adjacent to vegetation plots during the initial sampling showed SOC of $9.02 \pm 2.84 \%$ in unburned plots and $7.83 \pm 1.14 \%$ in burned plots (all reported errors are standard errors). At the initial sampling, no significant difference between SOC was found between burned and unburned sites (Kruskal-Wallis test, $p=1$ ).

\section{Percent Cover}

Vegetation showed strong but incomplete recovery of percent cover within 2 years following the fire (Fig. 3), with the most recovery taking place in the second year of the monitoring period (see Fig. 3a). Average percent cover in unburned plots was $100 \pm 0.5 \%$ for the duration of the study, with the exception of September 2014, when average percent cover in control plots was $95 \pm 2 \%$. One year after the fire, average percent cover in burned plots only reached $34 \pm 4 \%$. Vegetation experienced a large growth period the summer of 2014, and average percent cover of burned plots by September 2014 was $70 \pm 6 \%$, with three out of 21 plots observed at $100 \%$ cover. While winter rains from 2014 to 15 created a small reprieve from extreme to severe drought status (reflected in increased PDSI [Supplemental Fig. 1]), the last survey during May 2015 showed a similar average percent cover to the previous survey of $71 \pm 5 \%$ and only one of 21 plots had retained $100 \%$ cover [Supplemental Table 2]. All sampling periods were significantly different in percent cover between burned and unburned sites (Kruskal-Wallis test, $p<0.004)$.

\section{Spatial Recovery Pattern}

There was evidence of spatial patterning in vegetation recovery (Fig. 3b). By March 2014, quadrats closest to the margin of unburned salt marsh habitat (approx. $9 \mathrm{~m}$ ) had reached an average of $56 \pm 8 \%$ cover compared to less than $25 \%$ cover in quadrats mid and far from unburned habitat ( $18 \mathrm{~m}$ and $27 \mathrm{~m}$ ). The trend for higher recovery in the quadrats near to unburned salt marsh was maintained throughout the 2-years monitoring period, with the final monitoring period in May 2015 showing the closest quadrats having attained $88 \pm 3 \%$ cover compared to $58 \pm 13 \%$ and $68 \pm 8 \%$ cover for the mid and the far plots respectively. There were significant differences in percent cover between all burned plots by distances from unburned salt marsh for January and August of 2013 and March and April of 2014 (Kruskal-Wallis test, $p=0.07, p=0.09, p=$ $0.006, p=0.017$, respectively). Significantly higher percent cover was observed in plots $9 \mathrm{~m}$ to salt marsh edge compared to only sites $27 \mathrm{~m}$ from unburned salt marsh during six of the nine sampling periods (Kruskal-Wallis test, June, August, and October 2013, March and April 2014, and May 2015).

\section{Species Composition, Diversity, and Evenness}

For the majority of the study period the dominant species in all unburned quadrats was $S$. pacifica with an average cover of $67 \pm 3 \%$ (Fig. 3c). Frankenia grandifolia was the second most common species in unburned quadrats at $27 \pm 3 \%$ cover. Distichlis spicata averaged $6 \pm 2 \%$ cover during the study 
period, but generally did not represent more than $5 \%$ cover in unburned plots except for a sudden increase in September 2013 to $37 \pm 17 \%$ cover followed by a drastic decrease to 1 $\pm 0 \%$ cover in the next month.

In burned quadrats $D$. spicata was the most prevalent colonizer and remained dominant in the burned area until the end of the study period where it represented on average $43 \pm 8 \%$ of plots (Fig. $3 \mathrm{~d}$ ). As in the unburned plots, F. grandifolia was the second most dominant species in burned plots. Salicornia pacifica recolonization of the burned area occurred quite slowly and remained low, compared to dominance of $S$. pacifica in unburned plots. In spring 2015 S. pacifica reached a maximum of $32 \pm 8 \%$ cover in burned plots, half of the estimated average percent cover in unburned areas.

Only three species were observed within the study plots, which is not unusual for Pacific coast salt marshes that typically show distinct vegetation zonation based on abiotic conditions and inter-specific competition (Pennings and Callaway 1992). The Simpson's ID for the unburned plots therefore shows quite large fluctuations over the study period, likely due to the low species richness and seasonal changes in vegetation composition (Fig. 4). However, a linear model of the change in Simpson's ID over time shows no overall trend $\left[\mathrm{R}^{2}=0.01 ; p=0.77\right]$. In contrast, there is a positive linear trend in the species diversity over time in the burned plots $\left[\mathrm{R}^{2}=0.68 ; p=0.006\right]$. The increase is not, however, due to an increase in the number of species present but rather the evenness of distribution, as seen in the percent distribution shown in Fig. 3d.

NMDS shows that species composition is significantly different between burned and unburned sites throughout the entire monitoring period (95\% confidence interval) (Fig. 5). NMDS axis 1 is positively correlated with $D$. spicata and negatively correlated with $S$. pacifica, and NMDS axis 2 is positively correlated with $F$. grandifolia (Table 1). The temporal trend in unburned plots is circular and shows very little change over the monitoring period, aside from the September 2013 increase in D. spicata noted previously. For much of the monitoring period the general trend in burned sites is positive along NMDS axis 2, indicating increased $F$. grandifolia in burned sites. In September 2014 and May 2015, points move negatively along NMDS axis 1, as $S$. pacifica begins to increase in relative abundance compared to $D$. spicata for burned plots.

Table 1 NMDS Results. Results of species variable fitting of NMDS for burned and unburned plots.

\begin{tabular}{lllll}
\hline & MDS1 & MDS2 & $\mathrm{r} 2$ & $\mathrm{p}$ \\
\hline Distichlis & 0.99246 & 0.1226 & 0.9639 & $<0.001$ \\
Frankenia & -0.16161 & 0.98685 & 0.8745 & $<0.001$ \\
Salicornia & -0.72934 & -0.68416 & 0.9106 & $<0.001$ \\
\hline
\end{tabular}

\section{Soil Organic Carbon}

Following the initial sampling period with slightly higher, but not significant, SOC levels in unburned plots, SOC showed no significant difference between burned and unburned plots throughout the study (Fig. 6). Comparing average SOC between plots that had $>10 \%,>20 \%$, and $>30 \%$ cover to those that had less cover similarly showed no significant difference between means. Comparison between plots with higher cover than $30 \%$ was not possible as only one plot with $>40 \%$ cover was sampled for soil carbon. Average monthly values of SOC in all sites varied from $4.5 \pm 0.4 \%$ to $9.0 \pm 2.8 \%$ but had little temporal variability [Supplemental Table 3].

\section{Remote Sensing}

Remote sensing results echo the in situ observations, with a sustained period of suppressed NDVI values following the fire in 2013 and a slight recovery toward the beginning of 2015 (Fig. 7). This period of low NDVI is distinct from any period before the fire, March 2010 to April 2013, where NDVI variability responds positively to precipitation and negatively to temperature. NDVI values are depressed in spring of 2012 and 2013 compared to spring 2010 and 2011 as PDSI decreases and the region begins to experience moderate to severe drought. NDVI values are decreasing in April before the 2013 fire occurs, while temperature is high and precipitation is low. This drop coincides with the beginning of the extreme drought. Such a drop in NDVI indicates that pre-fire vegetation was unseasonably brown. After the fire in May 2013, NDVI values are not immediately at their lowest point but continue to decline until reaching their lowest point in JulyAugust 2013. NDVI remains lower than any other dry season in this record until a precipitation event in winter of 2014, when increased mean NDVI likely reflects the increase in percent cover seen during in situ surveys, and NDVI values more closely resemble values seen before the Camarillo Springs Fire.

\section{Discussion}

Vegetation monitoring following the 2013 Camarillo Springs Fire at Point Mugu shows fire produces a multi-year disturbance in a Pacific Coast salt marsh. Even 2 years after the fire occurred, percent cover and species composition of the burned area at Point Mugu show variation from unburned salt marsh conditions (see Fig. 8). We show that recovery is a multi-year process resulting in a shift in species evenness with a fine-scale geographic patterning favoring sites closest to unburned vegetation. The length of the recovery, comprising perhaps two to three breeding seasons, is particularly concerning in terms of impacts on endangered species, such as the Belding's savannah 


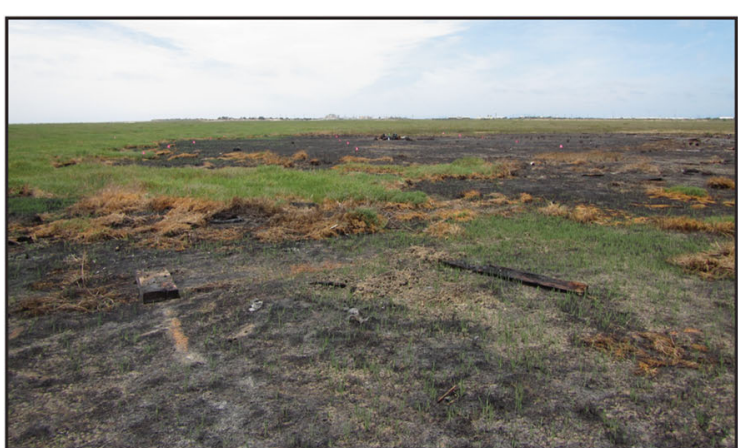

June 2013

Fig. 8 Pictures of Study Site Following Fire and During Recovery. Two photos taken looking east over the study site. The first was taken in June 2013 about 1 month following the Camarillo Springs Fire (photo

sparrow, with obligate salt marsh habitat requirements (Powell 1993). The 20-years recurrence interval between the Green Meadows Fire and the Camarillo Springs Fire indicate that, while fire may not be a documented disturbance in Salicornia spp.-dominated salt marshes, Salicornia marshes are at risk from disturbance by fire, especially in climate change conditions.

The gradual vegetation recovery in this study appears to be different from the rapid recovery of grass- and reed-dominant marshes to near pre-fire conditions within 1 year. While more intensive soil or peat burns have been shown to result in damage to SOC stock or increased SOM from increased productivity following biomass removal, we do not find any evidence to show that the Camarillo Springs Fire altered SOC content of burned and unburned soil, indicating a need for further research to understand post-fire wetland soil conditions. This study finds that fire in Pacific coast salt marshes could have long-term effects on ecosystem resilience in terms of vegetation recovery time which can impact ecosystem functionality and dependent species. Therefore a more intensive management response following disturbance by fire, especially in the case of ecosystems facing multiple stressors, may be required for Pacific coast salt marshes compared to their East coast counterparts.

\section{Vegetation Recovery Following Fire in Pacific Coast Salt Marshes}

Of particular concern for local ecosystem resiliency to fire is the slow recovery of the dominant vegetation type, $S$. pacifica, which serves as the species responsible for sediment trapping to maintain elevation increases with SLR because of the lack of Spartina at the site. Salicornia pacifica does not attain an average percent cover above $25 \%$ in burned areas compared to unburned averages which are consistently above $50 \%$ for entire study period. The slow recruitment of $S$. pacifica is also surprising given that a study in the nearby salt marsh at Tijuana River Estuary found recruitment of Salicornia spp.

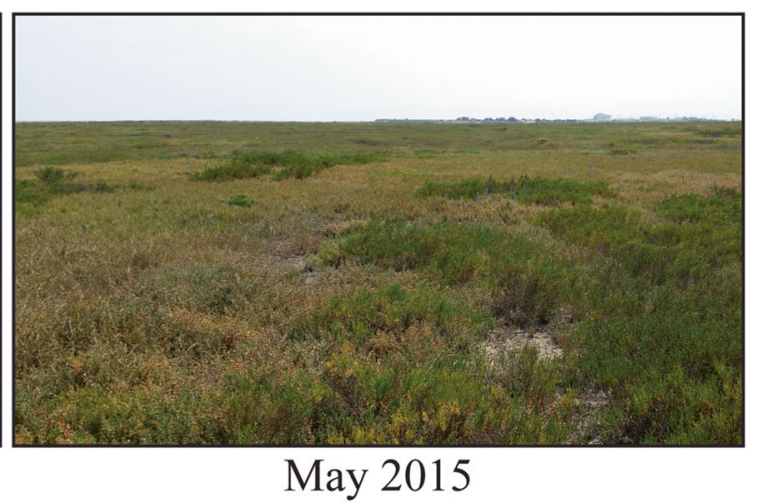

credit: Richard Ambrose). The second was taken during the final survey in May 2015 (photo credit: Lauren Brown)

and Suada esteroa dominated, among eight other identified species including $F$. grandifolia, in bare areas of a restoration site (Lindig-Cisneros and Zedler 2002). Moreover, seed banks of salt marshes in the San Francisco Bay area were shown to contain a majority Salicornia spp. seeds, with F. grandifolia and D. spicata comprising $<2 \%$ of the seedbank each (Hopkins and Parker 1984). Despite these previous studies showing $S$. pacifica recruits easily in Southern California salt marshes, recovery of $S$. pacifica following fire at Mugu was slow compared with other species.

The significantly higher recruitment observed in plots closest to unburned salt marsh suggests that recruitment following large disturbance events may be impeded by the distance to nonaffected salt marsh habitat. Such effects may have been especially pronounced due to the seasonality of the 2013 Camarillo Springs Fire. Seed dispersal in Pacific coast salt marshes is limited (Lindig-Cisneros and Zedler 2002) but occurs primarily in winter (Morzaria-Luna and Zedler 2007), so the seed bank would have been depleted for one entire growing season following the 2013 fire event. Observed spatial patterning could also be influenced by canopy removal causing increased solar radiation and loss of soil moisture. Those conditions would likely prevent $S$. pacifica and other salt marsh plants from establishing. The prevalence of $D$. spicata in recovered vegetation can also largely be attributed to its preference for disturbed sites (Hopkins and Parker 1984; Bertness 1991). Monotypic stands of D. spicata in the burned area and preference for sites closer to unburned salt marsh suggests a lack of seed availability and unsuitable environmental conditions in burned sites. Recovery could be accelerated by planting or seeding in areas that are disturbed.

The overall trend towards greater species evenness seen from the Simpson's ID of burned areas is an indication of higher vegetation diversity in burned areas, but, with no difference in the number of species observed in burned and unburned sites, the effect of this change in composition may be quite minimal. Even so, this change in species evenness could have implications for ecosystem functionality. Salicornia 
pacifica is the main ecosystem engineer in the Mugu Lagoon salt marsh and its decrease in percent cover could result in less sediment trapping and slower elevation gain. Our results, showing that S. pacifica is the slowest of the three observed vegetation types to recover, would indicate that small disturbances such as a fire could have long-term impacts on marsh resiliency to accelerated SLR.

Moreover, as the study site represents a very small area of the total area burned, we think these results do not fully capture some of the changes in vegetation composition that resulted from the 2013 Camarillo Springs Fire. Expansion of B. maritima was observed near some of the denuded salt pans and large, monotypic stands of Suaeda californica were seen in some burned areas above the frequently inundated tidal regions in the first year following the fire. These qualitative observations would point to higher rates of vegetation change following disturbance at upland-marsh transition zone which need to be explored further.

\section{Soil Organic Carbon}

Results indicating no difference in mean SOC between vegetated and unvegetated soil conditions may be related to the slow revegetation and drought seen in the study. Schmalzer and Hinkle (1992) found that SOM increased in burned areas for 9 months following a controlled burn in a mixed Juncus roemerianus and Spartina bakeri salt marsh, likely related to the increased productivity typically seen in bulrush and cordgrass marshes. No increase in SOC in burned sites at Mugu underscores that soil recovery, like vegetation recovery, is similarly slow at Mugu compared to marshes with documented burn records. Not all marshes show increased SOM following fire, however. Salvia et al. (2012) show fires occurring during a drought period in the Paraná River Delta in Argentina caused a decrease in SOC for a Schoenoplectus californicus and Cyperus giganteus marsh following burning which did not recover to SOC levels observed in unburned marsh during the year of monitoring. They conclude that recovery of vegetation and soil conditions largely depend upon the severity of the burn and the hydrological condition of the marsh. While the Camarillo Springs Fire does not appear to have been a high severity burn causing damage below the topsoil, low SOC $(<10 \%)$ may be more indicative of overall hydrological stress in both unburned and burned sites due to drought, rather than reflective of post-fire conditions. These very different wetland soil responses indicate a need for further research into how fire affects wetland soils with particular focus on hydrological conditions.

\section{Multiple Stressors}

The influence of drought on salt marsh vegetation and postfire recovery cannot be ignored. It is evident from NDVI that salt marsh vegetation was stressed due to climate conditions immediately before and during the recovery period. Drought in Southern California salt marshes has been linked to increased soil salinity (Zedler 2010), which decreases recruitment in most salt marsh species (Shumway and Bertness 1992). Seasonality and timing of precipitation can greatly influence recruitment success as well (Zedler 2010). The Camarillo Springs Fire occurred in May and cut the 2013 growing season short. Plants would have been recruiting after winter rains, when seed banks were depleted, past the peak growing season, and may have seen a higher proportion of die-off due to continued drought and soil salinity stress as summer progressed. These factors - the drought and the seasonality of the disturbance - may have significantly hindered the recovery at Mugu Lagoon. And while we cannot separate these effects in this study, decreased moisture and a longer fire season are predicted to become the norm under climate change conditions.

Although data on browned or dead vegetation were not collected in this study, it is a factor which should be considered in future research which tracks marsh vegetation recovery following disturbance or during drought. Salt marsh dieback, observed across the continental US, was linked to drought through PDSI along the southeast and Gulf coasts (Alber et al. 2008). The mechanisms which lead to sudden dieback are complex and often linked to interactive or additive stressors. Browned or dead cover will also affect soil conditions, such as sunlight receipt (Salvia et al. 2012), or waterflow across the site and could provide more insight into vegetative stress in recovery and control areas as well as provide an important parameter for further understanding of soil conditions.

Additionally, while there were no upland or non-marsh species in our direct study site, non-marsh species likely had an influence on recovery in other areas of the burn site. One year after the Camarillo Springs Fire, managers at Mugu started weed control for B. rapa, R. communis, A. donax, and others which had colonized the highest elevations in the burn area (personal communication, Valerie Vartanian). Many of these non-native or upland annuals have a competitive advantage over native high-elevation marsh and marsh peripheral vegetation in post-fire, disturbed soils (Zedler and Kercher 2004). Evidence points to a positive feedback between fire and upland species in many ecosystems (Brooks et al. 2010). Upland plants may cause long-term ecological modification through changes to canopy structure and soil moisture, preventing native high-elevation marsh and marsh peripheral vegetation from reestablishing. The upland ecotone in salt marshes on the Pacific Coast serves as critical habitat for pollinator and bird species which support the biodiversity of the salt marsh (Callaway and Zedler 2004) and the interaction between marsh and upland species will be a key issue in adaptation to accelerated SLR, as landward migration is the 
primary mechanism for salt marsh ecosystem adaptation to SLR (Kirwan et al. 2016). Repeated disturbances from fire and subsequent colonization by non-marsh species at the highest elevations of the marsh represents a secondary stressor on ecosystems already threated by SLR on the seaward margin with unknown long-term impacts on both marsh and upland transition zone ecology.

If climate change is increasing both the propensity of California salt marshes to burn and the length of time required for recovery it raises questions of salt marsh vulnerability to SLR as well as impact on ecosystem services, such as carbon storage in soils. Loss of remaining critical habitat will stress salt marsh biota, including listed species such as the Belding's savannah sparrow which might see local population collapse with habitat disturbances that impact two or more breeding seasons. Careful monitoring of the impact of not only the fire itself but also the additional stressors to the salt marsh ecosystem is needed. While examples from the Gulf and East coast ecosystems can provide some guidance as to how long-term recovery of ecosystem processes like accretion and carbon storage may progress after fire, the timing of the recovery in S. pacifica-dominated systems may result in vastly different outcomes. Multiple disturbances to salt marsh ecosystems have proven complex for ecosystem health and management (Martone and Wasson 2008; Zedler 2010). The Green Meadows and Camarillo Springs Fires highlight the need for ecosystem level management in the face of multiple environmental stressors, particularly in the face of accelerated SLR.

\section{Recommendations}

Given the serious implications of slow recovery of salt marsh species following fire, we recommend intensive monitoring and analysis of future fire disturbance in Pacific salt marshes, especially those dominated by S. pacifica. Such analysis should include the effects of vegetation denudation on sediment accretion rates, salt marsh elevation, and soil dynamics in addition to monitoring rate and composition of revegetation. Monitoring the interaction between non-marsh vegetation and native salt marsh plant revegetation should also occur, especially in the high-elevation marsh, as the impact of fire on this ecotone has not been documented before. Particular attention should be paid to multi-year disturbances of habitat critical for endangered species. In such cases of long-term disturbance on salt marsh ecosystems facing multiple, additive stressors, comprehensive ecosystem-wide monitoring will be needed to guide recovery efforts. With threats from accelerated SLR and urbanization, long-term disturbance from fire could have significant impacts on the resiliency of salt marsh habitat in the future.

Acknowledgements The authors would like to acknowledge staff, in particular Valerie Vartanian, at Naval Base Ventura County Point Mugu for their assistance with site access and guidance. They would also like to acknowledge Dr. Katherine Glover and Dr. James Holmquist for assistance with the initial sampling. Funding for this project was provided by the Southwest Climate Adaptation Science Center, Dr. Glen MacDonald, Principal Investigator.

Open Access This article is distributed under the terms of the Creative Commons Attribution 4.0 International License (http:// creativecommons.org/licenses/by/4.0/), which permits unrestricted use, distribution, and reproduction in any medium, provided you give appropriate credit to the original author(s) and the source, provide a link to the Creative Commons license, and indicate if changes were made.

\section{References}

Abatzoglou JT, McEvoy DJ, Redmond KT, Monitoring D, Fine Spatial Scales (2017) The west wide drought tracker: drought Monitoring at fine spatial Scales. Bulletin of the American Meteorological Society 98:1815-1820. https://doi.org/10.1175/BAMS-D-16-0193.1

Alber M, Swenson EM, Adamowicz SC, Mendelssohn IA (2008) Salt marsh dieback: an overview of recent events in the US. Estuarine, Coastal and Shelf Science 80:1-11. https://doi.org/10.1016/j.ecss. 2008.08.009

Barbier EB, Hacker SD, Kennedy C, Koch EW, Stier AC, Silliman BR (2011) The value of estuarine and coastal ecosystem services. Ecological Monographs 81:169-193. https://doi.org/10.1890/101510.1

Barnard PL, Li HE, Foxgrover AC, Hart JAF, Limber P, O'Neill AC, van Ormondt $\mathrm{M}$ et al (2019) Dynamic flood modeling essential to assess the coastal impacts of climate change. Scientific Reports 9:4309. https://doi.org/10.1038/s41598-019-40742-z

Bertness MD (1991) Interspecific interactions among high marsh perennials in a New England salt marsh. Ecology 72:125-137

Bickford WA, Needelman BA, Weil RR, Baldwin AH (2012) Vegetation response to prescribed fire in mid-Atlantic brackish marshes. Estuaries and Coasts 35:1432-1442. https://doi.org/10.1007/ s12237-012-9538-3

Brooks ML, D’Antonio CM, Richardson DM, Grace JB, Keeley JE, DiTomaso JM, Hobbs RJ, Pellant M, Pyke D (2010) Effects of invasive alien plants on fire regimes. BioScience 54:677-688

Callaway JC, Zedler JB (2004) Restoration of urban salt marshes: lessons from southern California. Urban Ecosystem 7:107-124. https://doi. org/10.1023/B:UECO.0000036268.84546.53

Chen J, Jönsson P, Tamura M, Gu Z, Matsushita B, Eklundh L (2004) A simple method for reconstructing a high-quality NDVI time-series data set based on the Savitzky-Golay filter. Remote Sensing of Environment 91:332-344. https://doi.org/10.1016/j.rse.2004.03.014

Chmura GL, Anisfeld SC, Cahoon DR, Lynch JC (2003) Global carbon sequestration in tidal, saline wetland soils. Global Biogeochemical Cycles 17. https://doi.org/10.1029/2002GB001917

Costanza R, D'Arge R, De Groot R, Farber S, Grasso M, Hannon B, Limburg K et al (1997) The value of the world's ecosystem services and natural capital. Nature 387:253-260. https://doi.org/10.1038/ $387253 \mathrm{a} 0$

Craft CB, Seneca ED, Broome SW (1991) Loss on ignition and Kjeldahl digestion for estimating organic carbon and Total nitrogen in estuarine marsh soils: calibration with dry combustion. Estuaries 14:175. https://doi.org/10.2307/1351691

Díaz-Delgado R, Lloret F, Pons X (2003) Influence of fire severity on plant regeneration by means of remote sensing imagery. International Journal of Remote Sensing 24. Taylor \& Francis Group:1751-1763. https://doi.org/10.1080/01431160210144732. 
Doughty CL, Cavanaugh KC, Ambrose RF, Stein ED (2019) Evaluating regional resiliency of coastal wetlands to sea level rise through hypsometry-based modeling. Global Change Biology 25. John Wiley \& Sons, Ltd (10.1111):78-92. https://doi.org/10.1111/gcb. 14429

Flores C, Bounds DL, Ruby DE (2011) Does prescribed fire benefit wetland vegetation? Wetlands 31:35-44. https://doi.org/10.1007/ s13157-010-0131-x

Florsheim JL, Chin A, Kinoshita AM, Nourbakhshbeidokhti S (2017) Effect of storms during drought on post-wildfire recovery of channel sediment dynamics and habitat in the southern California chaparral, USA. Earth Surface Processes and Landforms 42:1482-1492. https://doi.org/10.1002/esp.4117

Gabrey SW, Afton AD (2000) Effects of winter marsh burning on abundance and nesting activity of Louisiana seaside sparrows in the Gulf coast Chenier plain. The Wilson Bulletin 112:365-372. https://doi. org/10.1676/0043-5643(2000)112[0365:EOWMBO]2.0.CO;2

Griffin D, Anchukaitis KJ (2014) How unusual is the $2012-2014$ California drought ? Geophysical Research Letters 41:9017-9023. https://doi.org/10.1002/2014GL062433.1

Griggs G, Cayan D, Tebaldi C, Fricker H, Árvai J (2017) Rising seas in California. California Ocean Science Trust 71.

Heiri, O., Lotter, A. F., \& Lemcke, G. (2001). Loss on ignition as a method for estimating organic and carbonate content in sediments: reproducibility and comparability of results. Journal of paleolimnology, 25(1), 101-110.

Hopkins DR, Parker VT (1984) A Study of the Seed Bank of a Salt Marsh in Northern San Francisco Bay. American Journal of Botany 71. Botanical Society of America, Inc:348. https://doi.org/10.2307/ 2443494

Isacch JP, Holz S, Ricci L, Martínez MM (2004) Post-fire vegetation change and bird use of a salt marsh in coastal Argentina. Wetlands 24:235-243. https://doi.org/10.1672/0277-5212(2004)024[0235: PVCABU]2.0.CO;2

Johnson SR, Knapp AK (1993) The effect of fire on gas exchange and aboveground biomass production in annually vs biennially burned Spartina pectinata wetlands. Wetlands 13:299-303. https://doi.org/ 10.1007/BF03161296

Kern RA, Gregory Shriver W (2014) Sea level rise and prescribed fire management: implications for seaside sparrow population viability. Biological Conservation 173. Elsevier:24-31. https://doi.org/10. 1016/j.biocon.2014.03.007.

Kirwan ML, Walters DC, Reay W, Carr JA (2016) Sea level driven marsh expansion in a coupled model of marsh erosion and migration. Geophysical Research Letters 43:4366-4373. https://doi.org/10. 1002/2016GL068507

Komarek EV (1975) Fire ecology review. In Proceedings of the tall timbers fire ecology conference, 201-216.

Lindig-Cisneros R, Zedler JB (2002) Halophyte recruitment in a salt marsh restoration site. Estuaries 25. Coastal and Estuarine Research Federation:1174-1183. https://doi.org/10.1007/ BF02692214

Loveless C (1959) A study of the vegetation in the Florida Everglades. Ecology 40:1-9. https://doi.org/10.2307/1929916

Lynch JJ (1941) The place of burning in management of the Gulf coast wildlife refuges. The Journal of Wildlife Management 5:454-457

Mahall BE, Park RB (1976) The ecotone between Spartina foliosa Trin. And Salicornia virginica $L$. in salt marshes of northern San Francisco Bay: I. biomass and production. The Journal of Ecology 64:421-433

Martone RG, Wasson K (2008) Impacts and interactions of multiple human perturbations in a California salt marsh. Oecologia 158:151163. https://doi.org/10.1007/s00442-008-1129-4

Morzaria-Luna HN, Zedler JB (2007) Does seed availability limit plant establishment during salt marsh restoration? Estuaries and Coasts 30:12-25. https://doi.org/10.1007/BF02782963
Nagendra H (2002) Opposite trends in response for the Shannon and Simpson indices of landscape diversity. Applied Geography 22. Pergamon:175-186. https://doi.org/10.1016/S0143-6228(02) 00002-4

Nyman JA, Chabreck RH (1995) Fire in coastal marshes: history and recent concerns. In Fire in wetlands: a management perspective, 134-141.

O’Neil T (1949) The muskrat in the Louisiana coastal marshes.

Oksanen J (2015) Multivariate analysis of ecological communities in R: vegan tutorial. R Doc: 43.

Onuf CP (1987) The ecology of Mugu Lagoon, California: an estuarine profile. US Fish and Wildlife Service Biological Report 85(7.15).

Palmer WC (1965) Meteorological drought. US Department of Commerce, Weather Bureau, Washington, D.C

Pennings SC, Callaway RM (1992) Salt Marsh Plant zonation : the relative importance of competition and physical factors. Ecology 73: $681-690$

Pethick J (2001) Coastal management and sea-level rise. CATENA 42: 307-322. https://doi.org/10.1016/S0341-8162(00)00143-0

Powell AN (1993) Nesting Habitat of Belding's Savannah Sparrows in Coastal Salt Marshes 13: 219-223.

Purevdorj TS, Tateishi R, Ishiyama T, Honda Y (1998) Relationships between percent vegetation cover and vegetation indices. International Journal of Remote Sensing 19. Taylor \& Francis Group:3519-3535. https://doi.org/10.1080/014311698213795.

RC Team (2013) R: a language and environment for statistical computing

Reed M, Alvarez F (1993) Green meadow wildfire flares again : blazes: winds push flames through more than 750 acres. Officials are optimistic they will surround the new offshoot by this morning. Los Angeles Times, November 3.

Salvia M, Ceballos D, Grings F, Karszenbaum H, Kandus P (2012) Postfire effects in wetland environments: landscape assessment of plant coverage and soil recovery in the paraná river delta marshes, Argentina. Fire Ecology 8:17-37. https://doi.org/10.4996/ fireecology.0802017

Schmalzer PA, Hinkle CR (1992) Soil dynamics following fire in Juncus and Spartina marshes. Wetlands 12:8-21

Shumway SW, Bertness MD (1992) Salt stress limitation of seedling recruitment in a salt marsh plant community. Oecologia 92. Springer-Verlag:490-497. https://doi.org/10.1007/BF00317840

Smith RH (1942) Management of salt marshes on the Atlantic coast of the United States. In Trans North Am Wildl Conf., 7:272-277

Springs Fire Incident Information (2013) Cal Fire. May 11.

Stein ED, Cayce K, Salomon M, Bram DL, Grossinger R, Dark S (2014) Wetlands of the Southern California Coast: Historical Extent and Change Over Time. SCCWRP technical report 826, SFEI report 720. 2014. Costa Mesa, CA, Southern California Coastal Water Research Project

Stewart OC (1963) Barriers to understanding the influence of use of fire by aborigines on vegetation. In Proceedings of the tall timbers fire ecology conference, Vol. 2, 117-126

Stocker TF, Qin D, Plattner G-K, Tignor M, Allen SK, Boschung J, Nauels A, Xia Y, Bex V, Midgley PM (2013) IPCC, 2013: climate change 2013: the physical science basis. Contribution of Working Group I to the Fifth Assessment Report of the Intergovern- mental Panel on Climate Change. https://doi.org/10.1029/2000JD000115

Takekawa JY, Thorne KM, California Landscape Conservation Cooperative (2015) Tidal Marsh Digital Elevation Models (DEMs).

Thorne KM, MacDonald GM, Ambrose RF, Buffington KJ, Freeman CM, Janousek CN, Brown LN, et al. (2016) Effects of climate change on tidal marshes along a latitudinal gradient in California. Open-File Report. USGS Publications Warehouse. https://doi.org/ 10.3133/ofr20161125.

Thorne KM, MacDonald G, Guntenspergen G, Ambrose R, Buffington K, Dugger B, Freeman C, Janousek C, Brown L, Rosencranz J, Holmquist J, Smol J, Hargan K, Takekawa J (2018) U.S. Pacific 
coastal wetland resilience and vulnerability to sea-level rise. Science Advances 4:eaao3270

Uhler FM (1944) Control of undesirable plants in waterfowl habitats. In Transactions of the North American Wildlife Conference, Vol. 9, 29, 295-303.

Viosca P (1932) Spontaneous combustion in the marshes of southern Louisiana. Science (New York, N.Y.) 75:461-462. https://doi.org/ 10.1126/science.75.1948.461.

Westerling AL, Hidalgo HG, Cayan DR, Swetnam TW (2006) Warming and earlier spring increase western U.S. forest wildfire activity. Science (New York, N.Y.) 313:940-943. https://doi.org/10.1126/ science. 1128834

Yoon J-H, Kravitz B, Rasch PJ, Simon Wang S-Y, Gillies RR, Hipps L (2015) Extreme fire season in California: a glimpse into the future?
Bulletin of the American Meteorological Society 96:S5-S9. https:// doi.org/10.1175/BAMS-D-15-00114.1

Zedler JB (2010) How frequent storms affect wetland vegetation: a preview of climate-change impacts. Frontiers in Ecology and the Environment 8. Wiley-Blackwell:540-547. https://doi.org/10. 1890/090109

Zedler JB, Kercher S (2004) Causes and consequences of invasive plants in wetlands: opportunities, opportunists, and outcomes. Critical Reviews in Plant Sciences 23:431-452. https://doi.org/10.1080/ 07352680490514673

Publisher's Note Springer Nature remains neutral with regard to jurisdictional claims in published maps and institutional affiliations. 